\author{
Dr. sc. Mirza Čaušević, docent ${ }^{1}$ \\ Sveučilište/Univerzitet „VITEZ“, u Vitezu
}

\title{
ULOGA INSTITUCIJE OMBUDSMENA I SUDOVA U SUDSKIM POSTUPCIMA POVODOM SLUČAJEVA DISKRIMINACIJE U BOSNI I HERCEGOVINI ${ }^{2}$
}

\author{
UDK: 342(497.6) \\ DOI: $10.31141 /$ zrpfs.2019.56.133.667 \\ Pregledni znanstveni rad \\ Primljeno: 1. 12. 2018.
}

Prilikom čitanja samog naslova članka, nužno je istaknuti ulogu i značaj Institucije ombudsmena za ljudska prava Bosne i Hercegovine, najvažnije nacionalne institucije za zaštitu ljudskih prava i osnovnih sloboda. Shodno tome, po logici razmišljanja, jasno se može zaključiti da najvažniji segment djelovanja, gore pomenute nacionalne institucije, svakako jeste sprječavanje, odnosno eliminiranje svih oblika posredne i neposredne diskriminacije. U skladu s tim, autor je pored uvodnih i zaključnih razmatranja, članak odlučio podijeliti na četiri (4) radna dijela. U prvom dijelu članka, pod naslovom „Teorijska determiniranost diskriminacije“ daju se opšte informacije o pojmu, različitim oblicima i vrstama diskriminacije u skladu sa Zakonom o zabrani diskriminacije u Bosni i Hercegovini. Za razliku od prvog, u drugom dijelu članka „Uloga ombudsmena u sudskom postupku dokazivanja diskriminacije“ nastoji se prezentirati zakonska pozicija Ombudsmena u sudskom postupku, uz obaveznu naznaku uvjeta za pokretanje postupka u vlastito ime, zastupanje pojedinca i interveniranja u tekućem postupku. Kroz praktične primjere, autor nastoji da naglasi važnost, ulogu i značaj Ombudsmena u sudskim postupcima. Nakon toga, u trećem dijelu „Uloga sudova u sudskom postupku dokazivanja diskriminacije“ autor se koncentrira da, korištenjem Zakona o zabrani diskriminacije, prezentira sudske presude, kojima se obrazovni sistem Srednjobosanskog i Hercegovačko-neretvanskog kantona (ne)proglašava diskriminatornim na osnovu postojeće segregacije u tzv. „dvije škole pod jednim krovom“. Dakle, u ovom dijelu primarno se analizira odbijanje, gore navedenih, tužbenih zahtjeva. Na koncu, u četvrtom (radnom) dijelu pod nazivom „Proces dokazivanja diskriminacije pred Vrhovnim sudom Federacije Bosne i Hercegovine“ autor prezentira pozitivne i negativne primjere u radu Vrhovnog suda $\mathrm{FBiH}$, te se prevashodno pojašnjava proces dokazivanja diskriminacije pred ovom sudskom instancom. Cilj ovog rada podrazumijeva istraživanje pravne pozadine za djelovanje institucije ombudsmena za ljudska prava u Bosni i Hercegovini, kao i sudskih instanci s aspekta domaćeg (nacionalnog) prava, dok je, s druge strane, posebna pažnja posvećena djelovanju Vrhovnog suda FBiH u slučajevima diskriminacije.

Ključne riječi: Institucija ombudsmena za ljudska prava, diskriminacija, ljudska prava, Bosna i Hercegovina, Vrhovni sud Federacije Bosne i Hercegovine

1 Dr. sc. Mirza Čaušević, docent na Fakultetu pravnih nauka Sveučilišta/Univerziteta „,VITEZ“ u Vitezu,mirza.causevic@unvi.edu.ba.

2 Članak predstavlja rezultat rada na okruglom stolu „Djelovanje nadležnih tijela Bosne i Hercegovine u predmetima diskriminacije“, koji je organiziralo Sveučilište/Univerzitet „Vitez“ Vitez 27. I. 2018. godine. 


\section{UVODNA RAZMATRANJA}

Notorna je činjenica da pravo na nediskriminaciju predstavlja osnovni i ključni temelj realiziranja svih drugih ljudskih prava i sloboda. Zbog toga, zabrana diskriminacije definisana je brojnim međunarodnim dokumentima o ljudskim pravima, te je u potpunosti inkorporirana u moderne i demokratske pravne sisteme, kao jedan od brojnih ustavnopravnih principa. Dakle, sasvim je izvjesno da se nameće logična konstatacija da zabrana diskriminacije predstavlja fundamentalni ideal, koji teži ka potpunom afirmisanju principa jednakosti i ravnopravnosti u širokom dijapazonu društvenog života u bosanskohercegovačkom društvu. ${ }^{3}$

Bez obzira što je Ustav Bosne i Hercegovine (u daljnjem tekstu: Ustav) oktroiran, bitno je napomenuti da se već u prvoj alineji govori kako se cijeli društveni sistem Bosne i Hercegovine zasniva na poštivanju ljudskog dostojanstva, slobodi i jednakosti, kao centralnim i osnovnim društveno-pravnim vrijednostima. U skladu s tim, član II/4 Ustava, kao jedan od osnovnih principa u ostvarivanju ljudskih prava i sloboda predviđenih u ovom članu i u međunarodnim sporazumima pobrojanim u Aneksu I Ustava, navodi princip nediskriminacije. Shodno tome, međunarodni sporazumi iz Aneksa I Ustava direktno će se primjenjivati u Bosni i Hercegovini, a direktna primjena i prioritet nad ostalim zakonima predviđen je i u pogledu primjene Evropske konvencije za zaštitu ljudskih prava i osnovnih sloboda, kako je predviđeno članom II/2 Ustava. ${ }^{4}$

Donošenjem Zakona o zabrani diskriminacije Bosne i Hercegovine (u daljnjem tekstu: Zakon) u julu 2009. godine, kao i Zakona o izmjenama i dopunama Zakona o zabrani diskriminacije iz augusta 2016. godine, u Bosni i Hercegovini su jasno determinisani i apostrofirani svi modaliteti diskriminacije. Važno je naglasiti da je Zakon, takođe, naveo institucije nadležne za zaštitu od svih oblika diskriminacije, dok su detaljno pobrojani instrumenti i postupci za zaštitu od eventualnih diskriminatorskih ponašanja. $\mathrm{Na}$ osnovu definicija iz međunarodnih sporazuma o ljudskim pravima, uz saglasnost sa praksom Evropskog suda za ljudska prava, direktivama Evropske unije i djelovanjem Ujedinjenih nacija, Zakon je definisao elemente diskriminacije. ${ }^{5}$

Na osnovu Zakona, neophodno je naglasiti da su Institucija ombudsmena za ljudska prava u Bosni i Hercegovini i Ministarstvo za ljudska prava i izbjeglice Bosne i Hercegovine ključne institucije za zaštitu od diskriminacije. Samim tim, prema Zakonu, Institucija ombudsmena za ljudska prava u Bosni i Hercegovini centralna je institucija za borbu protiv diskriminacije. Takođe, njena primarna djelatnost je da zaprima žalbe građana, daje potrebna ovlaštenja i provodi postupke za zaštitu od diskriminacije. Shodno tome, druga nacionalna institucija zadužena za borbu protiv

3 Trnavci, G., Bešlagić, J. (2015.). Specifičnosti sudskih postupaka za zaštitu od diskriminacije u Bosni i Hercegovini. Pravni vjesnik, 31 (3-4), 297-309.

${ }^{4}$ Jović, I. M. (2013.). Mirovni ugovor (Dayton Peace Agreement). Kiseljak: Hrvatsko kulturno društvo „Napredak“.

5 Mitrović, Lj. (2017.). „Postupanje Ombudsmena za ljudska prava Bosne i Hercegovine u predmetima diskriminacije“, Pravni vjesnik, 33 (3-4), 165-177. 
diskriminacije je Ministarstvo za ljudska prava i izbjeglice Bosne i Hercegovine. Ministarstvo za ljudska prava i izbjeglice Bosne i Hercegovine prati provođenje Zakona, izvještava Vijeće ministara Bosne i Hercegovine i Parlamentarnu skupštinu Bosne i Hercegovine o pojavama diskriminacije i predlaže konkretne mjere za bolju i djelotvorniju zaštitu građana. Zakon predviđa i obaveznu saradnju nadležnih institucija sa organizacijama civilnog društva u donošenju strategija i planova, koja se odnose na pitanja diskriminacije. ${ }^{6}$

\section{TEORIJSKA DETERMINISANOST DISKRIMINACIJE}

Autor članka nastoji prvenstveno na pravni način definisati teorijsku determinisanost diskriminacije. Samim tim, veoma je jednostavno zaključiti da diskriminacija podrazumijeva ponašanje i djelovanje fizičkih ili pravnih lica, a koje ima proporcionalnu posljedicu kršenja uživanja ljudskih prava pojedincu ili grupi lica, i to isključivo zbog neke njihove lične ili životne karakteristike. ${ }^{7}$

Da bi se u potpunosti razjasnila teorijska uslovljenost diskriminacijskog manifestiranja volje u Bosni i Hercegovini, autor rada navodi definiciju diskriminacije, koja je obuhvaćena članom 2. stav 1. Zakona o zabrani diskriminacije. Dakle, u smislu prethodnog pomenutog Zakona, pod diskriminacijom će se smatrati ,svako različito postupanje uključujući svako isključivanje, ograničavanje ili davanje prednosti utemeljeno na stvarnim ili pretpostavljenim osnovama prema bilo kojem licu ili grupi lica i onima koji su s njima u rodbinskoj ili drugoj vezi na osnovu njihove rase, boje kože, jezika, vjere, etničke pripadnosti, invaliditet, starosna dob, nacionalnog ili socijalnog porijekla, veze s nacionalnom manjinom, političkog ili drugog uvjerenja imovnog stanja, članstva u sindikatu ili drugom udruženju, obrazovanja, društvenog položaja i spola, seksualne orijentacije, rodnog identiteta, spolnih karakteristika, kao i svaka druga okolnost koja ima za svrhu ili posljedicu da bilo kojem licu onemogući ili ugrožava priznavanje, uživanje ili ostvarivanje na ravnopravnoj osnovi, prava i sloboda u svim oblastima života."8

$\mathrm{Na}$ osnovu gore pomenute definicije, važno je determinisati pojam ,osnova diskriminacije“", pa se pod tim pojmom podrazumijeva „osobina ili karakteristika ili okolnost u kojoj se nalazi neko lice ili grupa lica, a to može biti rasa, boja kože, vjera, etnička pripadnost, nacionalno ili socijalno porijeklo, imovno stanje, pripadnost sindikatu, obrazovanje, spol, politički stav ili mišljenje kao i svaka druga okolnost, zbog koje se tom licu ili grupi lica samo zbog toga uskraćuje, krši ili

6 Vodič za zaštitu od diskriminacije kroz Zakon i Institucije (2011.). Prava za sve - učinimo ljudska prava stvarnim. Sarajevo: Fond otvoreno društvo Bosne i Hercegovine.

7 Reljanović, M. (2011.). Antidiskriminacioni okvir u Bosni i Hercegovini i zemljama Evropske unije. VIII naučni skup sa međunarodnim učešćem Sinergija, 23 (4), 74-86.

${ }^{8}$ Zakon o zabrani diskriminacije, Službeni glasnik Bosne i Hercegovine, br. 59/2009 i 66/2016. 
otežava uživanje nekog prava. "9 Shodno tome, ako neko lice ne prime na posao samo zbog različitog političkog opredjeljenja i mišljenja, govorimo o diskriminaciji po osnovu političkog stava. Ukoliko se konkursom za pojedino radno mjesto ne daju jednake šanse po pitanju godina, spola, izgleda, bračnog stanja, nacionalnosti radi se o diskriminaciji po osnovu spola, starosti i nacionalnosti. Dakle, u ovom slučaju se radi o tome da je neko lice uskraćeno da uživa pravo na rad samo zbog neke svoje karakteristike, a što je u potpunosti zabranjeno, gore navedenim, Zakonom. ${ }^{10}$

Sasvim je izvjesno da se diskriminacija može pojaviti u više različitih oblika nedozvoljenog postupanja. Samim tim, bitno je naznačiti da Zakon pravi diferencijaciju između neposredne ili direktne diskriminacije i posredne ili indirektne diskriminacije. Pod direktnom diskriminacijom podrazumijeva se svaka radnja činjenja ili nečinjenja, na osnovu koje se pojedino lice ili grupa osoba, zbog nekih određenih karakternih crta, različito tretira u odnosu na neku drugu osobu u pristupu proklamiranim pravima, a za takav diskriminatorski tretman nema zakonske svrhe i cilja, ili pak dolazi do primjene mjera koje nisu proporcionalne primarnom cilju koji se želi ostvariti. Za razliku od direktne, pod indirektnom diskriminacijom podrazumijevamo slučajeve postojanja naizgled neutralne odredbe, kriterija ili prakse, koja bi imala krajnji efekat dovođenja neke osobe ili grupe osoba u manje povoljan ili krajnje nepovoljan položaj u odnosu na druge osobe. ${ }^{11}$

Postoje i drugi oblici diskriminacije, koje Zakon decidno navodi u članu 4., a radi se isključivo o: uznemiravanju, seksualnom uznemiravanju, mobingu, segregaciji i podsticanju na diskriminaciju. Zakonodavac je precizno utvrdio da postoje teži oblici diskriminacije, pa diskriminaciju koja je počinjena po više osnova prema određenom licu kvalificira kao višestruku diskriminaciju, dok diskriminaciju koja je počinjena više puta označava kao ponovljenu diskriminaciju, da bi, na koncu, postulirao diskriminaciju koja postoji duže vrijeme kao produženu diskriminaciju. ${ }^{12}$

Pod uznemiravanjem podrazumijevamo svaku životnu situaciju, u kojoj diskriminirajuće ponašanje ima za cilj povredu digniteta diskriminirajućeg lica, i to isključivo samo zbog njegove pojedine karakteristike ili osobine uz stvaranje ponižavajućeg, uvrjedljivog, neprijateljskog, degradirajućeg i zastrašujućeg okruženja. Nadalje, postoji najteži oblik uznemiravanja, koje Zakon kvalifikuje kao seksualno uznemiravanje, te pod istim podrazumijeva svaki oblik neželjenog verbalnog ili neverbalnog i fizičkog ponašanja, koje je isključivo spolne prirode, a čiji je primarni cilj povreda dostojanstva diskriminirane osobe. Sasvim je logično da Zakon definiše mobing kao „oblik nefizičkog uznemiravanja na radnom mjestu

9 Priručnik za postupanje ombudsmena za ljudska prava Bosne i Hercegovine u predmetima diskriminacije (2016.). Institucija ombudsmena za ljudska prava u Bosni i Hercegovini. Sarajevo: Misija OSCE-a u Bosni i Hercegovini.

10 Hanušić, A. (2013.). Sudska zaštita od diskriminacije u Bosni i Hercegovini - Analiza zakonskih rješenja $i$ prakse u svjetlu prvih predmeta u ovoj oblasti. Sarajevo: Analitika - Centar za društvena istraživanja.

11 Zakon o zabrani diskriminacije, Službeni glasnik Bosne i Hercegovine, br. 59/2009 i 66/2016.

12 Vehabović, F., Izmirlija, M., Kadribašić, A. (2010.). Komentar Zakona o zabrani diskriminacije sa objašnjenjima i pregledom prakse u uporednom pravu. Sarajevo: Centar za ljudska prava Univerziteta u Sarajevu. 
koje podrazumijeva ponavljanje radnji koje imaju ponižavajući efekat na žrtvu čija je svrha ili posljedica degradacija radnih uslova ili profesionalnog statusa zaposlenog." ${ }^{13}$

Segregacija postoji kada neko fizičko ili pravno lice odvaja druga lica isključivo samo na osnovu neke njihove osobine, a najčešće se postulira kao rasna diskriminacija. Interesantno je napomenuti da bez obzira na evropsko pravo ljudskih prava i aspiracije Bosne i Hercegovine za članstvo u Evropskoj uniji, unutrašnji (nacionalni) i zakonski okvir Bosne i Hercegovine, njenih entiteta i kantona, u Srednjobosanskom i Hercegovačko-neretvanskom kantonu, još uvijek „gaji“ posebne oblike segregacije, i to kroz ,dvije škole pod jednim krovom “. ${ }^{14}$ Autor rada će na detaljan i opsežan način analizirati, gore pomenuti problem u nastavku članka. Interesantno je napomenuti, da je zakonodavac predvidio da je podsticanje na diskriminaciju jedan od oblika diskriminacije. Pod ovim se podrazumijeva, da kada na primjer tuženi svojim postupcima, ponašanjem i nekorektnim tolerisanjem diskriminirajuće atmosfere u ustanovi za koju je nadležan prešutno daje do znanja podređenim zaposlenicima da nema sklonosti i korektnosti prema pripadnicima određene grupe, a to ponašanje manifestuje kroz zagovaranje ili tolerisanje rasne, nacionalne ili vjerske mržnje. Pored toga, izdavanje naloga drugim licima da vrše diskriminaciju i pomaganje drugima prilikom diskriminacije je oblik diskriminacije. ${ }^{15}$

\section{ULOGA INSTITUCIJE OMBUDSMENA U SUDSKOM POSTUPKU DOKAZIVANJA DISKRIMINACIJE}

Po pitanju uloge Institucije ombudsmena u sudskom postupku dokazivanja diskriminacije, u skladu sa odredbama Zakona, ombudsmen(i) mogu potencirati na pokretanju prekršajnog postupka za zaštitu od diskriminacije. Pored toga, može se podnijeti krivična prijava u skladu sa općim pravilima krivičnog postupka. Sa druge strane, iluzorno je da, ombudsmen(i) Bosne i Hercegovine ne mogu pokrenuti parnični postupak, sa ciljem zaštite lica od diskriminacije. ${ }^{16}$

Dakle, kada ombudsmen(i) konstatiraju da je počinjena povreda prava i slobode podnosioca žalbe, mogu donijeti jednu od četiri vrste preporuka, i to: 1.) deklaratorna preporuka - preporuka kojom se utvrđuje da li se diskriminacija doista dogodila; 2.) konstitutivna ili preobražajna preporuka - ovom preporukom preporučuje se odgovornoj strani kako da utvrđenu diskriminaciju otkloni; 3.) preporuka sa

13 Zakon o zabrani diskriminacije, Službeni glasnik Bosne i Hercegovine, br. 59/2009 i 66/2016.

14 Miraščija, M. (2017.). Vodič za pravnu akciju protiv podjele đaka u Jajcu, $<$ http://www.skolegijum. ba/static/files/biblioteka/pdf/591ae6867513d_Jajcepravos.pdf>,pristupljeno 7. II. 2018.

15 Hanušić, A. (2013.). Sudska zaštita od diskriminacije u Bosni i Hercegovini - Analiza zakonskih rješenja i prakse u svjetlu prvih predmeta u ovoj oblasti. Sarajevo: Analitika - Centar za društvena istraživanja.

16 Hanušić, A. (2012.). Ombudsmen u sistemu zaštite od diskriminacije u Bosni i Hercegovini Analiza situacije i karakteristični problemi. Sarajevo: Analitika - Centar za društvena istraživanja. 
garancijom neponavljanja - odgovornoj strani daje se preporuka kako da uspostavi efikasan način buduće prevencije ponavljanja i 4.) preporuka za naknadu štete - odgovornoj strani daje se preporuka da razmotri zahtjev podnosioca žalbe za naknadu štete, svakako s ciljem prevencije (pre)skupih sudskih postupaka. ${ }^{17}$

Međutim, na prvi pogled, Zakon pruža mogućnost pokretanja parničnog postupka za zaštitu od diskriminacije. Veoma je zanimljivo napomenuti da Zakon o ombudsmenu za ljudska prava Bosne i Hercegovine u članu 4. stav 2. predviđa da ombudsmen(i) mogu ,pokrenuti sudske postupke ili intervenirati u toku postupka koji se vodi kad god ustanovi da je takva aktivnost neophodna pri obavljanju svojih dužnosti." ${ }^{18}$ Pored toga, Zakon o zabrani diskriminacije Bosne i Hercegovine ne bi trebao predstavljati dodatnu prepreku, s obzirom na činjenicu da u članu 17. daje aktivnu legitimaciju za sprovođenje parničnih postupaka za zaštitu od diskriminacije, i ustanovama i tijelima koje se „u okviru svoje djelatnosti bave zaštitom od diskriminacije određene grupe lica." ${ }^{19}$

Iako postoji zakonska mogućnost za aktivno djelovanje ombudsmena i u pravcu pokretanja sudskog postupka, dominira ključni stav i interpretacija da Institucija ombudsmena za ljudska prava nema nadležnost za pokretanje parničnog postupka. Veoma je interesantna izjava šefa Odjela za eliminaciju svih oblika diskriminacije u Instituciji ombudsmena za ljudska prava u Bosni i Hercegovini - gospodina Predraga Raosavljevića, koji smatra da bi korištenje mogućnosti pokretanja sudskog postupka zaštite od diskriminacije Instituciju ombudsmena Bosne i Hercegovine „odvuklo od primarne funkcije - preventivnog mehanizma zaštite ljudskih prava putem preporuka organima javne vlasti, prvenstveno na koji način da podignu standard zaštite." Njegovo mišljenje, kako ističe, bolje je da to nastave raditi advokati, organizacije i tijela koja su već ovlaštena za to, a da se Institucija ombudsmena ograniči na ukazivanje mogućnosti te zaštite, kao i na monitoring suđenja, odnosno, na analizu informacija prikupljenih sa suđenja i blagovremeno prenošenje zapažanja nadležnim institucijama u cilju poboljšanja realizacije i provedbe Zakona. ${ }^{20}$

Važno je ukazati na činjenicu da bi ekspertize Institucije ombudsmena, svakako mogle i morale biti ključni faktor uspjeha u rješavanju najtežih oblika diskriminacije. Pored toga, logično je da nije realno očekivati, da se Institucija ombudsmena pretvori u stalnog zastupnika žrtava diskriminacije u sudskom postupku. Na kraju krajeva, iz upotrebljene zakonske formulacije čini se da je namjera zakonodavca bila da ombudsmenu Bosne i Hercegovine omogući, u slučajevima u kojima to smatra

17 Mitrović, Lj. (2017.). „Postupanje Ombudsmena za ljudska prava Bosne i Hercegovine u diskriminacije“, Pravni vjesnik, 33 (3-4), 165-177.

18 Zakon o ombudsmenu za ljudska prava Bosne i Hercegovine, Službeni glasnik Bosne i Hercegovine, br. 19/2002, 35/2004 i 32/2006.

19 Zakon o zabrani diskriminacije, Službeni glasnik Bosne i Hercegovine, br. 59/2009 i 66/2016.

20 Raosavljević, P. (2012.). Lični intervju o oblicima diskriminacije u bosanskohercegovačkom društvu i oblicima prevazilaženja takvih negativnih stanja, <http://www.licni_intervju.ba/06/02/2012>, pristupljeno 6. II. 2018. 
neophodnim pri obavljanju svojih dužnosti, ostvarivanje potencijalno značajne uloge pokretanja sudskih postupaka u slučajevima diskriminacije. ${ }^{21}$

Shodno tome, Zakon o zabrani diskriminacije Bosne i Hercegovine ostavlja mogućnost Instituciji ombudsmena da kao treće lice ili „prijatelj suda“ (amicus curiae) učestvuje u postupku zaštite od diskriminacije na strani potencijalnih žrtava diskriminacije. Član 16., gore pomenutog Zakona, pri tome ovakav vid učešća uslovljava pristankom žrtava, te predviđa da bez obzira na ishod spora, treće lice ili umješač (intervenijent) ,sam snosi troškove svog učešća u parnici.“22 Kako pokazuju dosadašnja iskustva, opcije učešća Institucije ombudsmena u tekućem postupku u bosanskohercegovačkoj praksi još se ne koriste, što svakako predstavlja propust. Do sada nije bilo sudskih postupaka u kojima je ombudsmen učestvovao u vidu umješača na strani tužitelja, što se prevashodno objašnjava činjenicom da Institucija do sada nije zaprimila odgovarajući zahtjev u tom smislu. ${ }^{23}$

Nadalje, shodno gore navedenom, važno je napomenuti da se do sada nije desila situacija da sudovi zatraže mišljenje Institucije ombudsmena u vezi sa određenim pitanjem povodom dokazivanje diskriminatorskog ponašanja. Rješenje se pronalazi u smislu Zakona o zabrani diskriminacije Bosne i Hercegovine, u kojem zakonodavac predviđa u članu 17. stav 1. da ,udruženja ili druge organizacije osnovane u skladu sa zakonom, koje se bave zaštitom ljudskih prava, odnosno prava određene grupe lica, mogu podnijeti tužbu protiv lica koje je povrijedila pravo na jednako postupanje većeg broja lica koja pripadaju grupi čija prava tužilac štiti. “24

$\mathrm{Na}$ osnovu citiranja, gore navedenog člana Zakona, autor članka se koncentriše na dva predmeta u kojima je nevladina organizacija Vaša prava Bosne i Hercegovine (umješačili intervenijent) pokušala da, koristeći se Zakonom o zabrani diskriminacije, izdejstvuje sudske presude, kojima se obrazovni sistem Srednjobosanskog i Hercegovačko-neretvanskog kantona proglašava diskriminatornim na osnovu postojeće segregacije u tzv. „dvjema školama pod jednim krovom.“ Predmet autorove analize su razlozi odbijanja ovih tužbenih zahtjeva. Ključno je da autor članka, smatra dva problema najbitnijim, i to: prepoznavanje postojećeg problema kao političkog i samim tim, onog koji je van sfere sudskog odlučivanja, i prava nevladinih organizacija da zastupaju interese građana u sudskim sporovima. Iz navedenog, proizilazi, da iz analize ova dva problema, odnosno njihovog obrazloženja u sudskim presudama kojima se autor bavi u članku, mogu se utvrditi neki, ključni, sistemskih problema sa kojima se naše pravosuđe suočava. Ti problemi su: fokus na tumačenje proceduralnih, ali ne i materijalnih odredbi zakona, i očekivanja da pravosuđe bude avangarda borbe za zaštitu od diskriminacije..$^{25}$

21 Reljanović, M. (2011.). Antidiskriminacioni okvir u Bosni i Hercegovini i zemljama Evropske unije. VIII naučni skup sa međunarodnim učešćem Sinergija, 23 (4), 74-86.

22 Zakon o zabrani diskriminacije, Službeni glasnik Bosne i Hercegovine, br. 59/2009 i 66/2016.

23 Raosavljević, P. (2012.). Lični intervju o oblicima diskriminacije u bosanskohercegovačkom društvu i oblicima prevazilaženja takvih negativnih stanja, <http://www.licni_intervju.ba/06/02/2012>, pristupljeno 6. II. 2018.

${ }_{24}$ Zakon o zabrani diskriminacije, Službeni glasnik Bosne i Hercegovine, br. 59/2009 i 66/2016.

25 Hogić, N. (2014.). Nevoljki tumači zakona: sudovi i segregacija u Bosni i Hercegovini. Sarajevo: Centar za ljudska prava Univerziteta u Sarajevu. 
$\mathrm{Na}$ proceduralnom planu, potrebno je odgovarajućim propisom predvidjeti obavezu pružanja posebnog, jasnog i detaljnog obrazloženja suda u slučaju odstupanja od preporuke Institucije ombudsmena Bosne i Hercegovine. Ovim rješenjem, poznatim u komparativnoj praksi, postigla bi se bolja harmonizacija postupka pred ombudsmenom i onog pred sudom. Bazirajući se na postojećim zakonskim opcijama, Institucija ombudsmena Bosne i Hercegovine trebala bi preuzeti aktivniju ulogu u sudskom postupka. Lavina tužbi koje bi pokrenula ova institucija, i u skladu sa komparativnim iskustvima, ne može se očekivati, ali je značajno da i ekspertiza i iskustvo Institucije ombudsmena budu iskorišteni u strateškim predmetima, koji se odnose, na primjer, na pojave strukturalne diskriminacije, utvrđivanje precedenata ili razrješenje pojedinih pravila antidiskriminacionog zakonodavstva. Eventualne nedoumice $u$ pogledu aktivne legitimacije Institucije ombudsmena u ovom smislu moguće je riješiti traženjem autentičnog tumačenja konkretnih odredaba Zakona o ombudsmenu Bosne i Hercegovine i Zakona o zabrani diskriminacije Bosne i Hercegovine od zakonodavca. ${ }^{26}$

\section{ULOGA SUDOVA U SUDSKOM POSTUPKU DOKAZIVANJA DISKRIMINACIJE}

Sudski postupak za zaštitu od diskriminacije pokreće se posebnim tužbama, koje je Zakon o zabrani diskriminacije klasificirao, i to kao: tužba za utvrđivanje diskriminacije, tužba za zabranu ili otklanjanje diskriminacije, tužba za naknadu štete, tužba radi objavljivanja presude kojom se utvrđuje postojanje diskriminacije. ${ }^{27}$ Prethodno navedeni postupci pokreću se, vode i okončavaju prema pravilima parničnog postupka, ali u određenim slučajevima može se pokrenuti i krivični postupak, $i$ to isključivo onda kada se određeno diskriminatorno postupanje smatra krivičnim djelom. ${ }^{28}$ Iako, sudski postupci za zaštitu od diskriminacije imaju svoje specifičnosti definirane Zakonom o zabrani diskriminacije, čime se, na izvjestan način, odstupa od općih pravila parničnog postupka, a stepen zaštite žrtava diskriminacije podiže se na nivo više i permanentno se osigurava efikasnost zaštite putem ovog mehanizma. ${ }^{29}$

Nadalje, neophodno je spomenuti da se u postupcima za zaštitu od diskriminacije odstupa od klasičnog pravila o teretu dokazivanja (onus probandi) u parničnim postupcima, prema kojem je na onom koji tuži da i dokazuje navode svoje optužbe. ${ }^{30}$ Dakako, samim tim, jasno je da žrtva diskriminacije treba samo učiniti vjerovatnim

26 Hanušić, A. (2012.). Ombudsmen u sistemu zaštite od diskriminacije u Bosni i Hercegovini Analiza situacije i karakteristični problemi. Sarajevo: Analitika - Centar za društvena istraživanja.

27 Zakon o zabrani diskriminacije, Službeni glasnik Bosne i Hercegovine, br. 59/2009 i 66/2016.

28 Ibidem.

29 Trnavci, G., Bešlagić, J. (2015.). „Specifičnosti sudskih postupaka za zaštitu od diskriminacije u Bosni i Hercegovini“, Pravni vjesnik, 31 (3-4), 297-309.

30 Zakona o parničnom postupku Federacije Bosne i Hercegovine, ,Službene novine Federacije Bosne i Hercegovine“", broj 53/2003, 73/2005, 19/2006, 98/2015. 
da je do diskriminacije došlo, a sam izvršilac eventualne diskriminacije dužan je dokazati da diskriminacije nije bilo. ${ }^{31} \mathrm{~S}$ druge strane, ako tuženi sa određenim stepenom sigurnosti ne dokaže da diskriminacije nije bilo, sud je dužan utvrditi da je pravo na jednako postupanje povrijeđeno (in dubio pro discriminatione). Sasvim je logično, da se na ovaj način ukinulo neprikosnoveno pravilo da onaj ko nešto tvrdi to mora i da dokaže.

Interesantno je napomenuti da Zakon o zabrani diskriminacije u Bosni i Hercegovini predviđa i mogućnost sudjelovanja u sudskom postupku na strani tužioca, i to svim udruženjima, organizacijama, tijelima, ustanovama ili drugim licima koja se u okviru svojih djelatnosti bave zaštitom od diskriminacije lica ili grupe lica, o čijim se pravima direktno odlučuje u postupku. ${ }^{32} \mathrm{U}$ ovom slučaju radi se o „prijateljima suda“, odnosno umješačima ili intervenijentima na strani legitimnog javnog interesa, koji se u okviru svoje djelatnosti bave zaštitom prava na jednako postupanje u odnosu na grupe lica o čijim pravima se raspravlja u postupku. Na taj način, legitiman interes zasigurno bi imale različite organizacije, koje se bave pitanjima ljudskih prava i zaštitom od diskriminacije. ${ }^{33}$

$\mathrm{Na}$ osnovu prethodno elaboriranog, autor se opredijelio na prezentiranje prvog (strateškog) parničnog postupka, koji je inicirala nevladina organizacija „Vaša prava Bosne i Hercegovine“" (umješač ili intervenijent). Naime, oni su tužbom podignutom pred Općinskim sudom u Mostaru osporili zakonitost organiziranja obrazovnog sistema u Hercegovačko-neretvanskom kantonu, tvrdeći da je trenutni model u praksi diskriminatoran, jer proizvodi segregaciju učenika. Samim tim, u ovom se postupku „Vaša prava Bosne i Hercegovine“ pojavljuju kao zastupnik roditelja, iako su sama zastupana po punomoćniku - advokatu. Dakle, autor rada zastupa stajalište da je izvan svake sumnje tužitelj imao aktivnu legitimaciju za podnošenje tužbe, jer je to i smisao postojanja strateškog parničenja, kao procesnog instituta i norme sadržane u Zakonu. ${ }^{34}$

Nadalje, nužno je naznačiti da „Vaša prava Bosne i Hercegovine“, kao i druge organizacije, koje se bave pružanjem besplatne pravne pomoći, ne uživaju gotovo nikakvu podršku bosanskohercegovačkih vlasti na bilo kojem nivou. Nažalost, notorna je činjenica da Zakon o besplatnoj pravnoj pomoći nije donešen na državnom nivou, pa se može konstatirati da ova materija nije jednoobrazno i sistematski uređena. Očigledno je da na osnovu ovog propusta, nepostojanja pravnog okvira za besplatnu pravnu pomoć i nedovoljno preciznog normiranja procesnog položaja nevladinih organizacija, proizilaze mogućnosti različite interpretacije strateškog parničenja. ${ }^{35}$

31 Zakon o zabrani diskriminacije, Službeni glasnik Bosne i Hercegovine, br. 59/2009 i 66./2016.

32 Ibidem.

${ }_{33}$ Miraščija, M. (2017.). Vodič za pravnu akciju protiv podjele đaka u Jajcu, $<$ http://www.skolegijum. ba/static/files/biblioteka/pdf/591ae6867513d_Jajcepravos.pdf>,pristupljeno 7. II. 2018.

34 Zakon o zabrani diskriminacije, Službeni glasnik Bosne i Hercegovine, br. 59/2009 i 66./2016.

35 Savić, M. (2014.). Strateško parničenje u zaštiti od diskriminacije i besplatna pravna pomoć: (ne) jednak položaj organizacija civilnog društva u parničnim postupcima u Bosni i Hercegovini. Sarajevo: Centar za ljudska prava Univerziteta u Sarajevu. 
Uzmemo li u obzir sve faktore koje je autor determinisao u članku, nastoji se naglasiti primarna uloga sudova u sudskom postupku dokazivanja diskriminacije. Dakle, u samom sažetku rada navodi se da će se u trećem dijelu članka „Uloga sudova u sudskom postupku dokazivanja diskriminacije“" autor koncentrirati da korištenjem Zakona o zabrani diskriminacije, prezentira sudske presude, kojima se obrazovni sistem Hercegovačko-neretvanskog kantona proglašava diskriminatornim na osnovu postojeće segregacije u tzv. „dvije škole pod jednim krovom“.

Shodno tome, presudom Vrhovnog suda Federacije Bosne i Hercegovine od 29.08.2014. godine ukinuta je drugostepena presuda Kantonalnog suda u Mostaru povodom prakse u Federaciji Bosne i Hercegovine prema kojoj su djeca u osnovnim i srednjim školama izučavala različite nastavne programe, poznata pod nazivom „dvije škole pod jednim krovom“. Vrhovni sud Federacije Bosne i Hercegovine je odbacio drugostepenu presudu Općinskog suda u Mostaru i potvrdio prvostepenu presudu prema kojoj „,dvije škole pod jednim krovom“ predstavljaju etničku segregaciju učenika i naložio da takva praksa mora biti ukinuta. Shodno navedenom, presudom Vrhovnog suda Federacije Bosne i Hercegovine broj: 580 PS 08565313 REV od 29.08.2014. godine, uvažene su revizije Udruženja „Vaša prava Bosne i Hercegovine ", te je rješenje Kantonalnog suda u Mostaru broj: 58 OPS 08565312 PŽ od 11.06.2013. godine, preinačeno na način da se žalbe tuženika odbijaju i prvostepena presuda Općinskog suda u Mostaru broj: 580 PS 085653 11 PS od 27.04.2012. godine potvrđuje, a kojom je utvrđeno da su prvotuženi, Hercegovačko-neretvanski kanton, Ministarstvo obrazovanja, nauke, kulture i sporta, te drugotuženi, Osnovna škola Stolac i trećetuženi, Osnovna škola Čapljina organizovanjem škola na etničkom principu i donošenjem i primjenom školskih planova i programa na etničkom principu odvajali učenike u školama na području Hercegovačko-neretvanskog kantona na temelju njihove etničke pripadnosti čime su počinili diskriminaciju. ${ }^{36}$

Na bazi stava 2. dispozitiva prvostepene presude Općinskog suda u Mostaru naloženo je prvotuženom, s ciljem prestanka dalje diskriminacije djece u školama na području Hercegovačko-neretvanskog kantona, da najkasnije do 1. IX. 2012. godine, ustanovi jedinstvene integrisane multikulturalne obrazovne ustanove-škole za utvrđena upisna područja sa jedinstvenim nastavnim planom i programom, uz puno poštovanje prava djece na obrazovanje na maternjem jeziku, a drugo i trećetuženom da $\mathrm{u}$ istom roku integracijom stvore osnov multikulturalnosti škola i obrazovanja djece, bez obzira na etničku pripadnost, po jedinstvenom planu i programu na maternjem jeziku. ${ }^{37}$

Jednostavno je zaključiti, na osnovu tumačene problematike, da autor članka potencira na činjenici da do današnjeg dana nisu uspostavljene jedinstvene i multikulturalne obrazovne ustanove sa jedinstvenim nastavnim planom i programom,

36 Godišnji izvještaj o pojavama diskriminacije u Bosni i Hercegovini za 2014. godinu (2015.). Institucija ombudsmena za ljudska prava u Bosni i Hercegovini. Banja Luka: Institucija ombudsmena za ljudska prava.

37 Hogić, N. (2014.). Nevoljki tumači zakona: sudovi i segregacija u Bosni i Hercegovini. Sarajevo: Centar za ljudska prava Univerziteta u Sarajevu. 
uz puno i neophodno poštovanje prava djece na obrazovanje na maternjem jeziku. Dakle, logično je da veliki problem predstavlja činjenica da se sudske presude po pitanju ,dvije škole pod jednim krovom“ ne poštuju i ne sprovode u djelo, čime se detaljno razgrađuje pravni sistem Bosne i Hercegovine.

Međutim, suzbijanje diskriminacije u segmentu obrazovanja neophodna je šira građanska akcija koja će uključivati javnu debatu i kampanju javnog zagovaranja protiv segregacije u Bosni i Hercegovini. Sa druge strane, neophodno je navesti da pomalo čudi odsustvo bilo kakvog, aktivnijeg, angažmana nevladinih organizacija na zagovaranju ukidanja segregacije u obrazovanju Srednjobosanskog i Hercegovačkoneretvanskog kantona. ${ }^{38}$

\section{PROCES DOKAZIVANJA DISKRIMINACIJE PRED VRHOVNIH SUDOM FEDERACIJE BOSNE I HERCEGOVINE}

Po pitanju procesa dokazivanja diskriminacije pred Vrhovnim sudom Federacije Bosne i Hercegovine, autor rada, potencira na principu dokazivanja (ne) diskriminacije. Dakako, prezentirat će se jedna presuda Vrhovnog suda, i to sa kritičkog stajališta, jer predstavlja opasan presedan, koji u budućnosti može imati nesagledivo štetne posljedice po pitanju zaštite ljudskih prava i osnovnih sloboda u Bosni i Hercegovini.

Naime, u 2008. godini, Općina Glamoč raspisala je konkurs za izbor direktora/ ice dječijeg vrtića „Leptiric“". Po okončanju konkursne procedure, jedini prijavljeni kandidat na konkursu bila je Martina Janja Katović, profesorica predškolskog vaspitanja i dugogodišnja zaposlenica, gore pomenutog vrtića, kojoj je istekao prvi mandat direktorice istoimene ustanove. Dapače, nevjerovatno je da, gore pomenuta, nije postavljena za direktoricu u drugom mandatu, isključivo i samo zbog toga što je časna sestra. Nakon toga, uložena je tužba Općinskom sudu u Livnu, koji je blagovremeno diskriminaciju prepoznao, te naredio da se potvrdi tužiteljicino imenovanje za direktoricu vrtića. Nakon toga, Kantonalni sud u Livnu je prvostepenu presudu potvrdio. Međutim, sredinom 2014. godine, po reviziji tužene Općine Glamoč, Vrhovni sud Federacije Bosne i Hercegovine donio je poprilično zbunjujuću i nelogičnu presudu. Naime, po mišljenju Vrhovnog suda u predmetu Janje Martine Katović protiv Općine Glamoč, ukoliko se ,samo jedno lice prijavi na konkurs za radno mjesto, $i$ ako to lice, bez obzira na kvalifikacije $i$ njihovu superiornost, ne bude zaposleno zbog svoje vjerske pripadnosti, takvo lice, ipak, ne može biti diskriminisano." Isti zaključak se, slijedom iste logike, može izvesti čak i kada potencijalni poslodavac, inače organ lokalne samouprave, javno izjavi da jedini kandidat, bez obzira na kompetencije, nije zaposlen isključivo usljed lične karakteristike - vjeroispovijesti. Na osnovu konstatiranog, lako je

38 Ibidem. 
izvuči jedinstven i logičan zaključak da ova presuda predstavlja veoma opasan i rigidan presedan, koji omogućava dodatni prostor poslodavcima da otvoreno i slobodno diskriminišu, ukoliko pred sobom imaju samo jednog kandidata ili čak nekoliko kandidata koji imaju zajedničku ključnu karakteristiku, na osnovu koje se diskriminiše. Na osnovu tog shvatanja i obrazloženja Vrhovnog suda Federacije Bosne i Hercegovine poslodavci mogu otvoreno da kažu da neće zapošljavati redovnice, LGBT populaciju, Rome ili žene, ukoliko su se samo takvi kandidati prijavili, jer ih sud neće imati s čim uporediti!?!?39

Nažalost, veoma je demorališuće konstatirati da je Vrhovni sud Federacije Bosne i Hercegovine u potpunosti pogrešno interpretirao pravila zaštite od diskriminacije i time na cijelom pravnom prostoru Federacije Bosne i Hercegovine doveo u opasnost sve one sitne napretke, koji su u oblasti zaštite od diskriminacije, teškom mukom postignuti.

Vrhovni sud Federacije Bosne i Hercegovine je, dakako, propustio da u obrazloženju svoje odluke uvede kategoriju hipotetičkog komparatora, koja je odavno prisutna u pravnoj teoriji i praksi, u slučaju pravog komparatora. Dakako, važno je naznačiti da je ovakva praksa uobičajena u evropskim pravnim sistemima, a sa druge strane u potpunosti je prihvaćena od Suda pravde Evropske unije. Hipotetički komparatori se koriste, isključivo, u slučaju kada stvarnog komparatora nije moguće identifikovati, i to s ciljem olakšanja utvrđivanja činjenica, na osnovu kojih se može izvesti zaključak da je došlo do direktne ili indirektne diskriminacije. ${ }^{40}$ Naime, slično tome, Sud pravde Evropske unije je u predmetu Galine Meister, u kojem se radilo o višestrukoj diskriminaciji po osnovu dobi, spola i etničkog porijekla, u nedostatku pravog komparatora, uzeo u obzir historiju zapošljavanja mladih muškaraca, koji pripadaju većinskoj populaciji kod istog poslodavca. ${ }^{41}$

Dakle, shodno gore navedenoj logici zaključivanja, nije trebalo mnogo mašte da se konstatira i identifikuje hipotetički komparator i u predmetu Martine Janje Katović. Tadašnji načelnik Općine Glamoč Radovan Marković je posebno naznačio da bi bilo koja osoba, koja nije u odori časne sestre bila dobar kandidat, čime se naglasila diskriminatorska namjera u ovom slučaju. Samim tim, mogao je Vrhovni sud Federacije Bosne i Hercegovine, recimo, da preispita historiju zapošljavanja kod tužene općine u potrazi za nekim primjerom u kojem se za radno mjesto u nekoj drugoj javnoj ustanovi prijavio samo jedan kvalifikovan kandidat, koji, eto, nije nosio vjersku odoru, pa je ipak primljen u radni odnos. Pored toga, mogao je Vrhovni sud Federacije Bosne i Hercegovine, u nedostatku takvog primjera, da zamisli šta bi se dogodilo da je pored tužiteljice Janje Martine Katović zaista bio neki drugi kandidat koji bi čak imao i manje kvalifikacija od nje, ali koji nije

39 Ivanković-Tamamović, A. (2014.). Pogrešna logika dokazivanja u antidiskriminacionim predmetima: Slučaj Vrhovnog suda Federacije Bosne i Hercegovine. Sarajevo: Centar za ljudska prava Univerziteta u Sarajevu.

40 Ibidem.

${ }^{41}$ Court of Justice of the European Union, Galina Meister vs. Speech Design Career Systems GmbH, C-415/10, 19. IV. 2012. 
katolička redovnica. Po tome, sudeći, bar, po izjavi bivšeg načelnika Markovića, takav kandidat bi bio imenovan za direktora. ${ }^{42}$

$\mathrm{Na}$ osnovu gore tumačenog slučaja pred Vrhovnim sudom Federacije Bosne i Hercegovine, autor članka smatra da bi bilo nužno i neophodno navesti sudsku praksu Evropskog suda za ljudska prava u Strazburu, po ovom pitanju. Dakle, sam Evropski sud za ljudska prava, u nekoliko je navrata, pozvan da se očituje upravo po osnovu pitanja izražavanja vjerske pripadnosti kroz isticanje vjerskih simbola. Interesantno je da i Evropski sud za ljudska prava donosi nekoliko osporavanih i u najmanju ruku čudnih odluka. Tako na primjer, Sud je zaključio da diskriminacije nema ukoliko se ženama koje se pokrivaju u skladu sa muslimanskim običajem zabrani da pohađaju javne univerzitete, čak i u većinski muslimanskim državama. ${ }^{43}$ Slično tome, pripadnici islamske vjeroispovijesti, koji nisu uspjeli da dokažu da u bliskoj budućnosti imaju namjeru da grade minaret, u državi u kojoj je ustavom zabranjeno građenje minareta, nisu dokazali da ih se ta zabrana lično tiče, te nemaju status žrtve. ${ }^{44}$ Ipak, prihvatljivo je da se u većinski kršćanskoj državi u učionicama državnih škola, koje pohađaju i nekršćanska djeca drže vidno istaknuti kršćanski simboli. ${ }^{45}$ U skladu sa ovim standardima, u zavisnosti od toga da li je različit tretman u ovom predmetu učinjen na osnovu vjeroispovijesti ili na osnovu manifestacije vjeroispovijesti kroz odoru, Vrhovni sud Federacije Bosne i Hercegovine je svakako mogao argumentovati koji su standardi zaštite i mogućnosti državne intervencije u tom domenu. ${ }^{46}$

No, od svih ovih mogućnosti, Vrhovni sud je, nažalost, odabrao da pogrešno pristupi tumačenju komparatora $u$ antidiskriminacionim predmetima i tako dovede u pitanje buduću sudsku praksu u zaštiti od diskriminacije u Federaciji Bosne i Hercegovine. I na kraju ovog dijela članka, važno je napomenuti, da je u ovom slučaju, Vrhovni sud diskriminaciji dao vjetar u leđa, što je svojevrsni paradoks zemlje u kojoj živimo.

\section{ZAKLJUČNA RAZMATRANJA}

Na osnovu elaboriranja naučno-stručne tematike u ovom članku, autor konstatira da prvi, najvažniji, korak u zaštiti od diskriminacije jeste poznavanje zakona i korištenje prava i mehanizama zaštite. Dakako, efikasna zaštita je moguća samo

42 Topić, B. (2015.). Teret dokazivanja direktne i indirektne diskriminacije. Sarajevo: Centar za ljudska prava Univerziteta u Sarajevu.

43 European Court of Human Rights (ECtHR), Leyla Sahin vs. Turkey, aplikacija br. 44774/98, 10. XI. 2005.

44 Cour européenne des droits de 1'homme (CEDH), Ligue des Musulmans de Suisse et autres vs. Suisse, aplikacija br. 66274/09, 28. VI. 2011.

45 European Court of Human Rights (ECtHR), Lautsi and Others vs. Italy, aplikacija br. 30814/06, 18. III. 2011.

46 Ivanković-Tamamović, A. (2014.). Pogrešna logika dokazivanja u antidiskriminacionim predmetima: Slučaj Vrhovnog suda Federacije Bosne i Hercegovine. Sarajevo: Centar za ljudska prava Univerziteta u Sarajevu. 
ako se diskriminacija prijavi i pokrenu postupci pred institucijama za zaštitu od diskriminacije. Dakle, samim tim, uvijek se dobro obratiti organizacijama i udruženjima koje pružaju pravnu pomoć ili se bave zaštitom od diskriminacije ili zaštitom ljudskih prava (na primjer „Vaša prava Bosne i Hercegovine“). Konačno, Zakon nudi i neke nove mogućnosti uključenja organizacija u postupke za zaštitu na strani žrtve diskriminacije ili pokretanjem kolektivnih tužbi u slučaju diskriminacije prema grupi osoba.

Nadalje, autor u okviru zaključnih razmatranja tendenciono naznačava da tijela za zaštitu jednakosti mogu biti efikasno sredstvo zaštite pojedinca od diskriminacije. Poredeći ih sa sudskom zaštitom, ona mogu biti jednostavniji, brži i efikasniji način za ostvarivanje zaštite od diskriminacije. Da bi Institucija ombudsmena za ljudska prava Bosne i Hercegovine mogla postati istinski katalizator društvenih promjena $u$ ovoj oblasti, potrebno je, međutim, osigurati uslove za njeno nesmetano, nezavisno i efektivno djelovanje.

Shodno tome, autor članaka ne može da se složi sa distinkcijom između prava i politike koju je Kantonalni sud u Mostaru nastojao uspostaviti u obrazloženju svoje presude, pa na osnovu te konkluzije važno je napomenuti da je za rješavanje segregacije u bosanskohercegovačkim školama neophodno mnogo više od sudskih presuda i tumačenja Zakona o zabrani diskriminacije u Bosni i Hercegovini. Samim tim, ako želimo izbjeći segregaciju u školama, u promjenu političke i društvene svijesti moramo krenuti što prije, inače nam prijeti situacija u kojoj će segregacija formalno biti ukinuta, ali će nastaviti da egzistira kroz politiku upisivanja djece u škole bez formalnog etničkog predznaka, ali u praksi etničke čiste.

U slučaju djelovanja Vrhovnog suda Federacije Bosne i Hercegovine, ostaje postulirana činjenica da je Sud propustio da sankcioniše predstavnike vlasti u javnom iskazivanju netrpeljivosti zasnovane na vjerskoj pripadnosti. Srećom, odlukom Vrhovnog suda predmet Janje Martine Katović još uvijek nije dobio epilog. Sredinom 2017. godine Ustavni sud Bosne i Hercegovine donio je odluku po kojoj redovnica Janja Martina Katović nije imala pravično suđenje pred Vrhovnim sudom Federacije Bosne i Hercegovine. U skladu sa tim, odluka Ustavnog suda praktično znači da je predmet vraćen Vrhovnom sudu Bosne i Hercegovine na ponovni postupak. Krajnji epilog o ovom predmetu mogao bi da zaključi, Evropski sud za ljudska prava u Strazburu, kojem ne bi bio prvi put da diskutuje o slučajevima diskriminacije u Bosni i Hercegovini.

Doista, značajnija dostignuća u suzbijanju diskriminacije moguće je ostvariti samo kroz konstantne napore i inkrementalno unaprjeđenje u domenu primjene važećih propisa, kao i u edukaciji i stvaranju kulture tolerancije prema drugima koji su različiti i prevenciji diskriminatorskih postupanja i ponašanja. Dakle, dostupni empirijski pokazatelji ukuzaju na nototnu činjenicu da pravni subjekti u Bosni i Hercegovini relativno rijetko posežu za ovakvim pravnim mehanizmima u borbi protiv diskriminacije i da postojeća pravna praksa nije urodila željenim i očekivanim rezultatima pravne zaštite žrtava diskriminacije. U konačnici, željeni učinak promulgiranih reformi izostao je zbog odsustva iskrene političke volje nositelja 
političke vlasti da se krene u borbu protiv diskriminacije u bosanskohercegovačkom društvu. Autor se nada, da će se u skorije vrijeme, bosanskohercegovački politički establišment konstruirati bolji i pravedniji pravni sistem u kojem će se u potpunosti, u skladu sa evropskim vrijednostima štititi ljudska prava.

\section{LITERATURA}

\section{Knjige, priručnici, vodiči i članci}

1. Godišnji izvještaj o pojavama diskriminacije u Bosni i Hercegovini za 2014. godinu (2015.). Institucija ombudsmena za ljudska prava u Bosni i Hercegovini. Banja Luka: Institucija ombudsmena za ljudska prava.

2. Hanušić, A. (2012.). Ombudsmen u sistemu zaštite od diskriminacije u Bosni i Hercegovini - Analiza situacije i karakteristični problemi. Sarajevo: Analitika Centar za društvena istraživanja.

3. Hanušić, A. (2013.). Sudska zaštita od diskriminacije u Bosni i Hercegovini-Analiza zakonskih rješenja i prakse u svjetlu prvih predmeta u ovoj oblasti. Sarajevo: Analitika - Centar za društvena istraživanja.

4. Hogić, N. (2014.). Nevoljki tumači zakona: sudovi i segregacija u Bosni i Hercegovini. Sarajevo: Centar za ljudska prava Univerziteta u Sarajevu.

5. Ivanković-Tamamović, A. (2014.). Pogrešna logika dokazivanja u antidiskriminacionim predmetima: Slučaj Vrhovnog suda Federacije Bosne $i$ Hercegovine. Sarajevo: Centar za ljudska prava Univerziteta u Sarajevu.

6. Jović, I. M. (2013.). Mirovni ugovor (Dayton Peace Agreement). Kiseljak: Hrvatsko kulturno društvo „Napredak“.

7. Mitrović, Lj. (2017.). „Postupanje Ombudsmena za ljudska prava Bosne i Hercegovine u predmetima diskriminacije“. Pravni vjesnik, 33 (3-4), 165-177.

8. Priručnik za postupanje ombudsmena za ljudska prava Bosne $i$ Hercegovine u predmetima diskriminacije (2016.). Institucija ombudsmena za ljudska prava u Bosni i Hercegovini. Sarajevo: Misija OSCE-a u Bosni i Hercegovini.

9. Reljanović, M. (2011.). Antidiskriminacioni okvir u Bosni i Hercegovini i zemljama Evropske unije. VIII naučni skup sa međunarodnim učešćem Sinergija, 23 (4), 74-86.

10. Savić, M. (2014.). Strateško parničenje u zaštiti od diskriminacije i besplatna pravna pomoć: (ne)jednak položaj organizacija civilnog društva u parničnim postupcima u Bosni i Hercegovini. Sarajevo: Centar za ljudska prava Univerziteta u Sarajevu.

11. Topić, B. (2015.). Teret dokazivanja direktne i indirektne diskriminacije. Sarajevo: Centar za ljudska prava Univerziteta u Sarajevu.

12. Trnavci, G., Bešlagić, J. (2015.). „Specifičnosti sudskih postupaka za zaštitu od diskriminacije u Bosni i Hercegovini“. Pravni vjesnik, 31 (3-4), 297-309.

13. Vehabović, F., Izmirlija, M., Kadribašić, A. (2010.). Komentar Zakona o zabrani diskriminacije sa objašnjenjima i pregledom prakse u uporednom pravu. Sarajevo: Centar za ljudska prava Univerziteta u Sarajevu. 
14. Vodič za zaštitu od diskriminacije kroz Zakon i Institucije (2011.). Prava za sve - učinimo ljudska prava stvarnim. Sarajevo: Fond otvoreno društvo Bosne i Hercegovine.

\section{Zakonski i drugi propisi}

1. Ustav Bosne i Hercegovine, Aneks 4 Dejtonskog mirovnog sporazuma za Bosnu i Hercegovinu.

2. Zakon o ombudsmenu za ljudska prava Bosne i Hercegovine, Službeni glasnik Bosne i Hercegovine, br. 19/2002, 35/2004 i 32/2006.

3. Zakon o zabrani diskriminacije, Službeni glasnik Bosne i Hercegovine, br. 59/2009 i $66 / 2016$.

4. Zakona o parničnom postupku Federacije Bosne i Hercegovine, „Službene novine Federacije Bosne i Hercegovine“, broj 53/2003, 73/2005, 19/2006, 98/2015.

\section{Sudske odluke}

1. Court of Justice of the European Union, Galina Meister vs. Speech Design Career Systems GmbH, C-415/10, 19. IV. 2012.

2. Cour européenne des droits de l'homme (CEDH), Ligue des Musulmans de Suisse et autres vs. Suisse, aplikacija br. 66274/09, 28. VI. 2011.

3. European Court of Human Rights (ECtHR), Lautsi and Others vs. Italy, aplikacija br. 30814/06, 18. III. 2011.

4. European Court of Human Rights (ECtHR), Leyla Sahin vs. Turkey, aplikacija br. 44774/98, 10. XI. 2005.

\section{Internetski izvori}

1. Miraščija, M. (2017.). Vodič za pravnu akciju protiv podjele đaka u Jajcu, $<$ http:// www.skolegijum.ba/static/files/biblioteka/pdf/591ae6867513d_Jajcepravos.pdf>, Pristupljeno 7. II. 2018.

2. Raosavljević, P. (2012.). Lični intervju o oblicima diskriminacije u bosanskohercegovačkom društvu i oblicima prevazilaženja takvih negativnih stanja, $<$ http://www.licni_intervju.ba/06/02/2012>, pristupljeno 6. II. 2018. 


\section{THE ROLE OF THE OMBUDSMAN AND COURT INSTITUTIONS IN JUDICIAL PROCEEDINGS WITH THE DISCUSSION OF DISCRIMINATION IN BOSNIA AND HERZEGOVINA}

When reading the article's title, it is important to emphasize the role and importance of the Institution of the Ombudsman for Human Rights of Bosnia and Herzegovina, the most important national institution for the protection of human rights and fundamental freedoms. Consequently, according to the logic of thinking, it can be clearly concluded that the most important segment of action, above mentioned national institution, is to prevent or eliminate all forms of indirect and direct discrimination. Accordingly, the author decided, in addition to introductory and concluding considerations, to divide the article into four (4) parts. The first part of the article entitled "Theoretical Determination of Discrimination" provides general information on the concept, different forms and types of discrimination in accordance with the Law on Prohibition of Discrimination in Bosnia and Herzegovina. Unlike the first, in the second part of the article "The Role of the Ombudsman in the Probation of Discrimination Proceedings", the Ombudsman aims to present the legal position of the ombudsman in court proceedings, with the mandatory indication of the conditions for initiating the proceedings on his own behalf, representing the individual and intervening in the ongoing proceedings. Through practical examples, the author seeks to emphasize the importance, role and importance of the ombudsman in court proceedings. Subsequently, in the third part of the "Role of Courts in the Probation of Discrimination Proceedings", the author concentrates that, by using the Law on Prohibition of Discrimination, he presents court judgments that discriminate the education system of the Central Bosnia and Herzegovina Canton (non) discriminatory on the basis of the existing segregation in so called. "Two schools under one roof". Thus, this section primarily analyzes the rejection of the aforementioned claims. Finally, in the fourth (working) section entitled "The Probation of Discrimination Proceeding before the Supreme Court of the Federation of Bosnia and Herzegovina", the author presents positive and negative examples in the work of the Supreme Court of $\mathrm{FBiH}$, and above all clarifies the process of proving discrimination before this court instance. The aim of this paper is to investigate the legal background of the Institution of the Ombudsman for Human Rights in Bosnia and Herzegovina, as well as judicial instances from the aspect of domestic (national) law, while, on the other hand, special attention is devoted to the actions of the $\mathrm{FBiH}$ Supreme Court in cases of discrimination.

Keywords: Ombudsman Institution for Human Rights. -Discrimination. - Human rights. - Bosnia and Herzegovina. - Supreme Court of the Federation of Bosnia and Herzegovina. 